Огляди літератури, оригінальні дослідження, погляд на проблему, випадок з практики, короткі повідомлення УДК 616.36-003.826:616-008.83]-074

DOI 10.11603/1811-2471.2020.v.i2.11337

\title{
ЗМІНИ РІВНЯ Р-СЕЛЕКТИНУ У СИРОВАТЦІ КРОВІ У ХВОРИХ НА НЕАЛКОГОЛЬНУ ЖИРОВУ ХВОРОБУ ПЕЧІНКИ
}

\author{
๑є. С. Сірчак, В. І. Грига, А. В. Стегура, А. І. Гольча \\ ДВНЗ «Ужгородський національний університет»
}

РЕЗЮМЕ. Неалкогольна жирова хвороба печінки (НАЖХП) охоплює спектр захворювань, тісно пов'язаних із метаболічними факторами ризику. Внаслідок інсулінорезистентності (IP) у хворих з метаболічним синдромом, цукровим діабетом (ЦД) 2-го типу, НАЖХП, формується дисфункція ендотелію (ДЕ).

Мета - дослідити особливості зміни рівня Р-селектину в сироватці крові у хворих на НАЖХП залежно від наявності чи відсутності ЦД 2-го типу та порушення вгодованості.

Матеріал і методи. Обстежено 104 хворих на НАЖХП. Хворих поділено наступним чином: в 1.1 підгрупу увійшли 22 хворих на неалкогольний жировий гепатоз (НАЖГ) та IP, 1.2 підгрупу склали 30 пацієнтів із НАЖГ та ЦД 2-го типу; в 2.1 підгрупу увійшли 26 хворих на неалкогольний стеатогепатит (НАСГ) та IP, а 2.2 підгрупу склали 26 хворих на НАСТ та ЦД 2-го типу. Усім обстеженим пацієнтам проведено загальноклінічні дослідження, а також визначення рівня Р-селектину у сироватці крові.

Результати. Встановлено підвищення рівня Р-селектину у всіх обстежених нами підгрупах пацієнтів. Виявлено стадійність підвищення його концентрації у сироватці крові із прогресуванням ураження печінки (від НАЖГ до НАСГ), а також його поєднання з IP чи ЦД 2-го типу. Максимальний рівень Р-селектину визначено у хворих 2.2 підгрупи $((445,81 \pm 9,13)$ нг/мл, р<0,01), а мінімальний - у хворих 1.1 підгрупи $((226,14 \pm 7,56)$ нг/мл, $p<0,05)$.

Висновки. У хворих на НАЖХП встановлено підвищення рівня Р-селектину у сироватці крові, що має стадійний характер, із максимальним його відхиленнями від норми при НАСГ у поєднанні з ЦД 2-го типу та мінімальними змінами у хворих з НАЖГ та ІР. У хворих на НАЖХП та порушення вуглеводного обміну (IP чи ЦД 2-го типу) рівень Р-селектину підвищується відповідно до збільшення індексу маси тіла із максимальними показниками у пацієнтів з ожирінням II ступеня.

КлючОВІ СлОВА: неалкогольна жирова хвороба печінки; інсулінорезистентність; цукровий діабет; Р-селектин.

Вступ. Неалкогольна жирова хвороба печінки (НАЖХП) охоплює спектр захворювань, тісно пов'язаних із метаболічними факторами ризику. На сьогодні доведена спільність патогенетичних механізмів для НАЖХП та метаболічного синдрому і стає очевидним їх зв'язок із цукровим діабетом (ЦД) 2-го типу, серцево-судинними захворюваннями і тяжкими формами захворювання печінки, включно з цирозом і гепатоцелюлярною карциномою [1].

Вважають, що центральне місце у розвитку НАЖХП відіграє інсулінорезистентність (IP) [2]. Унаслідок IP у хворих з метаболічним синдромом, ЦД 2-го типу, НАЖХП тощо формується дисфункція ендотелію, а також судинна резистентність до інсуліну у поєднанні з метаболічною резистентністю до інсуліну, що сприяє розвитку гіпертензії і серцево-судинних ускладнень [3].

Отже, дослідження різних біологічно активних речових, які мають здатність впливати на стан судинного ендотелію у хворих на НАЖХП, особливо при його поєднанні з IP та ЦД 2-го типу, є актуальним питанням у хворих з поєднаною патологією.

Мета - дослідити особливості зміни рівня Р-селектину у сироватці крові у хворих на НАЖХП залежно від наявності чи відсутності ЦД 2-го типу та порушення вгодованості.
Наукове дослідження $\epsilon$ фрагметном держбюджетної теми кафедри хірургічних хвороб та кафедри пропедевтики внутрішніх хвороб медичного факультету ДВНЗ «УжНУ» № 851 «Механізми формування ускладнень при захворюваннях печінки та підшлункової залози, методи їх лікування та профілактики», номер державної реєстрації: 0115U001103), а також наукової теми кафедри пропедевтики внутрішніх хвороб «Поліморбідна патологія при захворюваннях органів травлення, особливості патогенезу, можливості корекції (номер державної реєстрації 0118U004365).

Матеріал і методи дослідження. На клінічній базі кафедри пропедевтики внутрішніх хвороб медичного факультету ДВНЗ «УжНУ» (гастроентерологічне та ендокринологічне відділення КНП «ЗОКЛ імені А. Новака» ЗОД) за 2016-2020 рр. о6стежено 104 хворих на НАЖХП. Середній вік становив $(49,5 \pm 8,3)$ років. Хворих поділено на дві групи залежно від стадії ураження печінки, а саме:

- в I групу увійшли 52 хворих на неалкогольний жировий гепатоз (НАЖГ) (серед них чоловіків було 31 (59,6 \%), жінок 21 (40,4 \%); середній вік становив $(48,4 \pm 5,2)$ років)

- II групу склали 52 хворих на неалкогольний стеатогепатит (НАСГ) (серед них чоловіків було 32 (61,5\%), жінок 16 (38,5\%; середній вік становив $(49,0 \pm 67,7)$ років). 
Огляди літератури, оригінальні дослідження, погляд на проблему, випадок з практики, короткі повідомлення

Для вирішення поставленої мети хворих на НАЖХП по групах також поділили залежно від наявності ЦД 2-го типу (легкий ступінь тяжкості) чи IP (рис. 1).

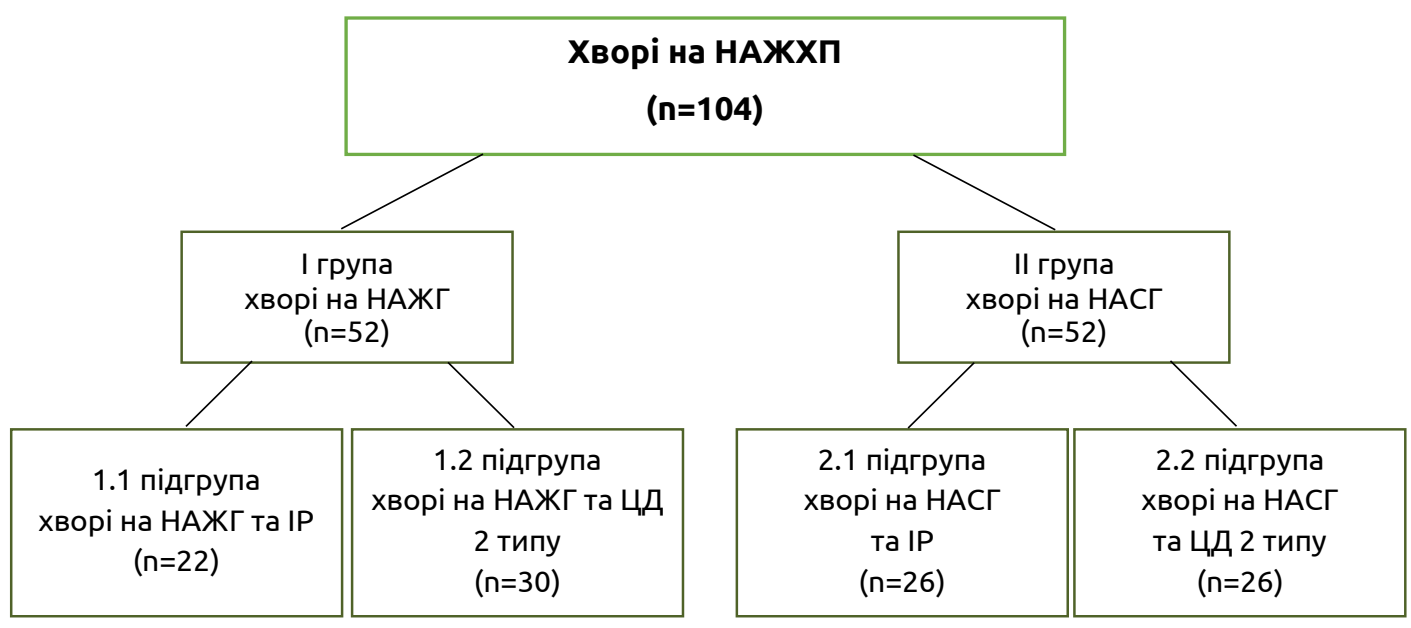

Рис. 1. Розподіл обстежених хворих на неалкогольну жирову хворобу печінки залежно від наявності інсулінорезистентності або цукрового діабету 2-го типу.

У контрольну групу ввійшли 20 практично здорових осіб (чоловіків було 12 (60,0\%), жінок $8(40,0 \%)$. Середній вік складав $(47,6 \pm 5,8)$ років.

Усі дослідження були виконані за згодою пацієнтів (від усіх хворих було отримано письмову згоду на проведення відповідних діагностичнолікувальних заходів), а методика їх проведення відповідала Гельсінській декларації прав людини 1975 р. та її перегляду 1983 р., Конвенції Ради Європи про права людини і біомедицину та законодавству України.

Усіх пацієнтів обстежували з використанням загальноклінічних, антропометричних, інструментальних та лабораторних методів. Для верифікації діагнозу звертали увагу на характер скарг і анамнез захворювання. При антропометричному дослідженні визначали зріст, вагу, обвід талії, а також розраховували індекс маси тіла (IMT) пацієнтів. Згідно з рекомендаціями ВООЗ, хворих поділили залежно від показника IMT - IMT 16,0 і менше відповідав вираженому дефіцитові маси тіла; 16,018,5 - недостатній масі тіла; 18,0-24,9- нормальній масі; 25,0-29,9 - надмірній масі; 30,0-34,9 - ожирінню I ступеня; 35,0-39,9 - ожирінню II ступеня; 40,0 i більше - ожирінню III ступеня [4].

Усім хворим виконано ультразвукове дослідження органів черевної порожнини за загальноприйнятою методикою. У сироватці крові проведено стандартні загальні та біохімічні дослідження для визначення функціонального стану печінки, показників ліпідного обміну, вуглеводного обміну (глюкози, інсуліну, глікозильованого гемоглобіну (HbA1c, \%).

Ультразвукове дуплексне сканування плечової артерії (ПА) виконували на апараті HDI-1500 (США) з використанням імпульсно-хвильового доплерівського датчика 2,5 мГц і 5-10 мГц - «Zonarae» (США). Ендотелійзалежну (ЕЗВД) та ендотелійнезалежну (ЕНВД) вазодилатацію ПА вивчали за методом, запропонованим D. Celermajer [5].

Діагноз НАЖХП встановлювали згідно з критеріями уніфікованого клінічного протоколу (наказ МОЗ України від 06.11.2014 р. № 826) та клінічними рекомендаціями EASL-EASD-EASO щодо діагностики та лікування НАЖХП [11]. Ступінь ураження печінки розраховували з використанням сурогатних маркерів фіброзу за допомогою онлайн-калькуляторів NAFLD fibrosis score (NFS), Fibrosis 4 calculator (FIB-4), а також фібротесту.

Діагноз ЦД 2-го типу встановлено згідно з рекомендаціями IDF (2005 р.), а також із урахуванням критеріїв уніфікованого клінічного протоколу (наказ МОЗ України від 21.12.2012 № 1118) [6, 7]. Ступінь тяжкості ЦД 2-го типу оцінювали за рівнем HbA1с (норма - до 6,0 \%).

У всіх обстежених нами хворих на НАЖХП та ЦД 2-го типу в сироватці крові методом імуноферментного аналізу проводили визначення показника Р-селектину з використанням тест-системи фірми «еBioscience» (Австрія).

Аналіз і обробку результатів обстеження хворих здійснювали за допомогою комп'ютерної програми STATISTICA 10.0 (фірми StatSoft Inc, USA) 3 використанням параметричних та непараметричних методів оцінки отриманих результатів.

Результати й обговорення. Результати антропометричного дослідження вказують на порушення індексу маси тіла у переважної більшості обстежених пацієнтів з НАЖХП. При цьому, як наведено у таблиці 1, як у групі хворих на НАЖГ, так і 
Огляди літератури, оригінальні дослідження, погляд на проблему, випадок з практики, короткі повідомлення

Таблиця 1. Розподіл обстежених хворих на неалкогольну жирову хворобу печінки залежно від показника індексу маси тіла

\begin{tabular}{|c|c|c|c|c|}
\hline \multirow{3}{*}{ Показник } & \multicolumn{4}{|c|}{ Обстежені хворі на НАЖХП } \\
\hline & \multicolumn{2}{|c|}{ I група (n=52) } & \multicolumn{2}{|c|}{ II група $(n=52)$} \\
\hline & $\begin{array}{c}1.1 \text { підгрупа } \\
(\mathrm{n}=22)\end{array}$ & $\begin{array}{c}1.2 \text { підгрупа } \\
(n=30)\end{array}$ & $\begin{array}{l}2.1 \text { підгрупа } \\
(\mathrm{n}=26)\end{array}$ & $\begin{array}{c}2.2 \text { підгрупа } \\
(\mathrm{n}=26)\end{array}$ \\
\hline $\begin{array}{l}\text { Нормальна вага, \% } \\
\text { (IMT 18,0 - 24,9) }\end{array}$ & $13,6 * \wedge$ & 3,3 & $7,6^{*}$ & $3,8 \%$ \\
\hline $\begin{array}{l}\text { Надмірна вага, \% } \\
\text { (IMT 25,0 - 29,9) }\end{array}$ & $40,9 * *, \wedge$ & 20,0 & $30,8 * *$ & $15,4 \%$ \\
\hline $\begin{array}{l}\text { Ожиріння I ст., \% } \\
\text { (IMT 30,0 - 34,9) }\end{array}$ & 27,3 & $53,4^{* *},++$ & $38,5^{\wedge}$ & $34,6 \%$ \\
\hline $\begin{array}{l}\text { Ожиріння II ст., \% } \\
\text { (IMT 35,0 - 39,9) }\end{array}$ & 18,2 & 23,3 & $23,1 \%$ & $26,2 \%$ \\
\hline
\end{tabular}

Примітка. Різниця між показниками у хворих I та II груп по підгрупах достовірна: * - p<0,05; різниця між показниками 1.1 та 2.1 підгруп достовірна: ^ - p<0,05; різниця між показниками 1.2 та 2.2 підгруп достовірна: + - p<0,05.

серед обстежених із НАСГ у поєднанні з IP (1.1 та 2.1 підгрупи) переважали особи з надмірною вагою тіла та ожирінням I ступеня. Слід зазначити, що на стадії ураження печінки, що відповідає НАСГ у поєднанні з ЦД 2-го типу, на 7,7 \% частіше діагностовано ожиріння I ст., ніж надмірна вага тіла, тоді як у підгрупі хворих з НАСГ та IP на 23,6 \% частіше встановлену надмірну вагу, порівняно із ожирінням I ст.

У хворих 1.2 та 2.2 підгруп (НАЖГ та НАСГ у поєднанні з ЦД 2-го типу) частіше визначали ожи- ріння I та II ступенів. У цих підгрупах обстежених нормальна вага діагностована лише у $3,3 \%$ та у $3,8 \%$ обстежених, а надмірна вага - у $20,0 \%$ та 15,4 \% обстежених відповідно.

Визначення інструментальних показників порушення стану ендотелію підтверджує факт його дисфункції (ДЕ) у хворих на НАЖХП. При цьому, зміни мають стадійний характер, тобто із прогресуванням ураження печінки, а також за ії поєднання з ЦД 2-го типу, більш виражено змінюються показники ЕЗВД та ЕНВД (табл. 2).

Таблиця 2. Зміни показників дисфункції ендотелію та Р-селектину в обстежених хворих на неалкогольну жирову хворобу печінки

\begin{tabular}{|c|c|c|c|}
\hline \multirow{2}{*}{ Обстежені } & \multicolumn{3}{|c|}{ Показник } \\
\hline & ЕЗВД, \% & ЕНВД, \% & Р-селектин, нг/мл \\
\hline Контрольна група & $13,74 \pm 2,12$ & $24,78 \pm 2,04$ & $118,23 \pm 5,51$ \\
\hline \multicolumn{4}{|l|}{ I група (n=52) } \\
\hline 1.1 підгрупа (n=22) & $11,22 \pm 0,50$ & $18,44 \pm 1,06$ & $226,14 \pm 7,56^{*}$ \\
\hline 1.2 підгрупа (n=30) & $10,71 \pm 0,52$ & $17,79 \pm 1,12^{*}$ & $298,40 \pm 7,31 *$ \\
\hline \multicolumn{4}{|l|}{ II група $(n=52)$} \\
\hline 2.1 підгрупа (n=26) & $9,51 \pm 0,44$ & $16,01 \pm 1,23 *$ & $358,77 \pm 6,55^{* *}$ \\
\hline 2.2 підгрупа (n=26) & $8,23 \pm 0,45^{*}$ & $15,35 \pm 1,01^{*}$ & $445,81 \pm 9,13^{* *},+$ \\
\hline
\end{tabular}

Примітка. Відмінності між показниками контрольної групи та обстеженими пацієнтами достовірні: * - p<0,05; ** - p<0,01; різниця між показниками 2.1 та 2.2 підгруп достовірна: + - p<0,05.

При характеристиці зміни рівня Р-селектину, як одного із лабораторних маркерів ДЕ, виявлено його підвищення у всіх обстежених нами підгрупах пацієнтів. Слід зауважити стадійність підвищення його концентрації у сироватці крові із прогресуванням ураження печінки (від НАЖГ до НАСГ), а також його поєднання з IP чи ЦД 2-го типу. Максимальний рівень Р-селектину визначений у хворих 2.2 підгрупи $((445,81 \pm 9,13) \mathrm{нг} /$ мл, $\mathrm{p}<0,01)$, а мінімальний - у хворих 1.1 підгрупи $((226,14 \pm 7,56)$ нг/мл, p $<0,05)$. Ми охарактеризували також залежність зміни рівня Р-селектину у хворих на НАЖХП та по- рушення вуглеводного обміну від зміни вгодованості у обстежених хворих (табл. 3).

Виявлена сильна кореляційна залежність між показником Р-селектину та надмірною вагою тіла у хворих на НАЖГ та НАСГ у поєднанні з IP $(r=0,78$; p<0,01 та г=0,62; $p<0,05$ відповідно). При ожирінні I ст. статистично достовірний зв'язок між збільшенням рівня Р-селектину встановлено у хворих 1.2 підгрупи, а також у хворих з НАСГ, як при поєднанні його з IP, так і з ЦД 2-го типу.

Аналіз отриманих даних вказує на підвищення концентрації Р-селектину у сироватці крові, як 
Огляди літератури, оригінальні дослідження, погляд на проблему, випадок з практики, короткі повідомлення

Таблиця 3. Зіставлення показників Р-селектину в сироватці крові з вираженістю порушення вгодованості в обстежених хворих

\begin{tabular}{|l|c|c|c|c|}
\hline \multirow{2}{*}{ Показник } & \multicolumn{3}{|c|}{ Обстежені хворі на НАЖХП } \\
\cline { 2 - 5 } & \multicolumn{2}{|c|}{$\begin{array}{c}\text { I група } \\
(\mathrm{n}=52)\end{array}$} & \multicolumn{2}{c|}{$\begin{array}{c}\text { II група } \\
(\mathrm{n}=52)\end{array}$} \\
\cline { 2 - 5 } & $\begin{array}{c}1.1 \text { підгрупа } \\
(\mathrm{n}=22)\end{array}$ & $\begin{array}{c}1.2 \text { підгрупа } \\
(\mathrm{n}=30)\end{array}$ & $\begin{array}{c}2.1 \text { підгрупа } \\
(\mathrm{n}=26)\end{array}$ & $\begin{array}{c}2.2 \text { підгрупа } \\
(\mathrm{n}=26)\end{array}$ \\
\hline Надмірна вага & $\mathrm{r}=0,78 ; \mathrm{p}<0,01$ & - & $\mathrm{r}=0,62 ; \mathrm{p}<0,05$ & - \\
\hline Ожиріння І ст. & - & $r=0,82 ; \mathrm{p}<0,01$ & $\mathrm{r}=0,72 ; \mathrm{p}<0,01$ & $\mathrm{r}=0,69 ; \mathrm{p}<0,05$ \\
\hline
\end{tabular}

одного із лабораторних маркерів ДЕ, в усіх групах обстежених нами пацієнтів. Як вказують отримані нами результати, максимальне відхилення показника даної біологічно активної речовини від норми встановлено у хворих із НАСГ у поєднанні з ЦД 2-го типу та ожирінням різного ступеня вираженості.

Відомо, що Р-селектин «з'являється» при агрегації тромбоцитів у місцях пошкодження судинної стінки, а також збільшення його рівня в організмі пов'язане з вивільненням прозапальних цитокінів у тканинах внутрішніх органів. При метаболічно обумовлених захворюваннях, до яких належать перераховані вище патологічні стани, порушення цитокінової ланки організму є одним із компонентів їх патогенезу, а також вказує на прогресування ускладнень при них. Активація Р-селектину, що регулює адгезію лейкоцитів, на нашу думку, відбувається як відповідь на запалення в тканинах і на початкових стадіях патологічного процесу спрямована на збереження цілісності ендотеліальної вистилки судин внутрішніх органів. Якщо на початкових етапах це відбувається як захисна реакція, то в подальшому, при вичерпанні компенсаторних резервів організму, ці активовані клітини адгезії

\section{ЛІТЕРАТУРА}

1. Неалкогольна жирова хвороба печінки: особливості метаболічних змін на різних етапах розвитку хвороби / Ю. М. Степанов, Н. В. Недзвецька, В. Б. Ягмур, І. А. Кленіна] // Гастроентерологія. - 2018. - Т. 52, № 1. C. $13-18$.

2. Asrih M. Inflammation as a potential link between nonalcoholic fatty liver disease and insulin resistance / M. Asrih, F. R. Jornayvaz // Journal of Endocrinology. 2013. - Vol. 218 (3). - P. 25-36.

3. Zheng C. Vascular function, insulin action and exercise: An intricate interplay / C. Zheng, L. Zhenqi // Trends Endocrinol. Metab. - 2015. - No. 26 (6). - P. 297-304.

4. WHO: Global Database on Body Mass Index. URL : http://apps.who.int/bmi/index.jsp?introPage=intro_3. html
(Р-селектин), сприяють розвитку/виникненню запальних змін у внутрішніх органах. При цьому приєднується новий компонент, який відповідає за хронізацію ураження у внутрішніх органах - а саме формування дисфункції ендотелію, особливо при коморбідних метаболічно індукованих патологічних станах, таких як НАЖХП, ЦД, ожиріння.

Висновки. 1. У хворих на НАЖХП встановлено підвищення рівня Р-селектину в сироватці крові, що має стадійний характер, із максимальним його відхиленнями від норми при НАСГ у поєднанні $з$ ЦД 2-го типу та мінімальними змінами у хворих 3 НАЖГ та IP.

2. У хворих на НАЖХП та порушення вуглеводного обміну (IP чи ЦД 2-го типу) рівень Р-селектину підвищується відповідно до збільшення IMT із максимальними показниками у пацієнтів з ожирінням II ступеня.

Перспективи подальших досліджень. Подальше вивчення змін рівнів біологічно активних речовин, у тому числі Р-селектину та його ролі у формуванні ускладнень у хворих на НАЖХП та порушення вуглеводного обміну для розробки ефективних методів їх профілактики та лікування.

5. Endothelium-dependent dilation in the systemic arteries of asymptomatic subjects relates to coronary risk factor and their interaction / D. S. Celermajer, K. E. Sorensen, C. Bull [et al.] // J. Am. Coll.Cariol. - 1994. - No. 24 (6). P. $1468-1474$.

6. Цукровий діабет 2 типу / [М. К. Хобзей, М.В.Гульчій, А. В. Степаненко та ін.] // Уніфікований клінічний протокол первинної та вторинної (спеціалізованої) медичної допомоги. - Київ, 2012. - 118 с.

7. Цукровий діабет 2 типу / [М. В. Гульчій, Л. Ф. Матюха, В. З. Нетяженко та ін.] // Адаптована клінічна настанова, заснована на доказах. - Київ, 2012. - 343 с. 
Огляди літератури, оригінальні дослідження, погляд на проблему, випадок з практики, короткі повідомлення REFERENCE

1. Stepanov, Yu.M., Nedzvetskaya, N.V., Yagmur, V.B., \& Klenina, I.A. (2018). Nealkoholna zhyrova khvoroba pechinky: osoblyvosti metabolichnykh zmin na riznykh etapakh rozvytku khvoroby [Non-alcoholic fatty liver disease: features of metabolic changes at different stages of the disease]. Hastroenterolohiia - Gastroenterology, 52 (1), 13-18. DOI: $10.22141 / 2308-2097.52 .1 .2018 .130772$ [in Ukrainian].

2. Asrih, M., \& Jornayvaz, F.R. (2013). Inflammation as a potential link between nonalcoholic fatty liver disease and insulin resistance. Journal of Endocrinology, 218 (3), 25-36. DOI: 10.1530/JOE-13-0201.

3. Zheng, C., \& Zhenqi, L. (2015). Vascular function, insulin action and exercise: An intricate interplay. Trends Endocrinol. Metab., 26 (6), 297-304. DOI:10.1016/j.tem.2015.02.002

4. WHO: Global Database on Body Mass Index. Retrieved from: http://apps.who.int/bmi/index.jsp?introPage= intro_3.html
5. Celermajer, D.S., Sorensen, K.E., Bull, C., Robinson, J., \& Deanfield, J.E. (1994). Endothelium-dependent dilation in the systemic arteries of asymptomatic subjects relates to coronary risk factor and their interaction. J. Am. Coll.Cariol., 24 (6), 1468-1474.

6. Hobzei, M.K., Hulchii, M.V., \& Stepanenko, A.V. (2012). Unifikovanyi klinichnyi protocol pervynnoi ta vtorynnoi (spetsializovanoi) dopomohy [Unified clinical protocol for primary and secondary (specialized) medical care]. Kyiv. Retrieved from: http://ukrgastro.com.ua/klinichni-protokoli-ta-nastanovi/ [in Ukrainian].

7. Hobzei, M.K., Matyuha, L.F., \& Netiazhenko, V.Z. (2012). Tsukrovyi diabet 2 typu. Adaptovana klinichna nastanova, zasnovana na dokazakh diabet 2 typu [Type 2 diabetes mellitus. Adapted clinical guideline based on evidence]. Kyiv. Retrieved from: http://ukrgastro.com.ua/klinichni-protokoli-ta-nastanovi/ [in Ukrainian].

\title{
ИЗМЕНЕНИЯ УРОВНЯ Р-СЕЛЕКТИНА В СЫВОРОТКЕ КРОВИ У БОЛЬНЫХ НЕАЛКОГОЛЬНОЙ ЖИРОВОЙ БОЛЕЗНЬЮ ПЕЧЕНИ
}

\author{
๑Е. С. Сирчак, В. И. Грига, А. В. Стегура, А. И. Гольча \\ ГВУЗ «Ужгородский национальный университет»
}

РЕЗЮМЕ. Неалкогольная жировая болезнь печени (НАЖБП) охватывает спектр заболеваний, тесно связанных с метаболическими факторами риска. Вследствие инсулинорезистентности (ИР) у больных с метаболическим синдромом, сахарным диабетом (СД) 2-го типа, НАЖБП, формируется дисфункция эндотелия (ДЭ).

Цель - изучить особенности изменения уровня Р-селектина в сыворотке крови у больных НАЖБП в зависимости от наличия или отсутствия СД 2-го типа и нарушения упитанности.

Материал и методы. Обследовано 104 больных НАЖБП. Больные распределены следующим образом: в 1.1 подгруппу вошли 22 больных с неалкогольным жировым гепатозом (НАЖГ) и IP, 1.2 подгруппу составили 30 пациентов с НАЖГ и СД 2-го типа; в 2.1 подгруппу вошли 26 больных неалкогольным стеатогепатитом (НАСГ) и IP, а 2.2 подгруппу составили 26 больных НАСГ и СД 2-го типа. Всем обследованным пациентам проведены общеклинические исследования, а также определение уровня Р-селектина в сыворотке крови.

Результаты. Установлено повышение уровня Р-селектина во всех обследованных нами подгруппах пациентов. Выявлена стадийность повышения его концентрации в сыворотке крови в зависимости от прогрессирования поражения печени (от НАЖГ до НАСГ), а также его сочетания с IP или СД 2-го типа. Итак, максимальный уровень Р-селектина выявлен у больных 2.2 подгруппы $((445,81 \pm 9,13)$ нг/мл, $p<0,01)$, а минимальный у больных 1.1 подгруппы $((226,14 \pm 7,56) \mathrm{Hг} / \mathrm{M}, \mathrm{p}<0,05)$.

Выводы. У больных НАЖБП установлено повышение уровня Р-селектина в сыворотке крови, которое имеет стадийный характер, с максимальными его отклонениями от нормы при НАСГ в сочетании с СД 2-го типа и минимальными изменениями у больных с НАЖГ и ИР. У больных НАЖБП и нарушениями углеводного обмена (ИР или СД 2-го типа) уровень Р-селектина повышается по мере увеличения индекса массы тела с максимальными показателями у пациентов с ожирением II степени.

КЛЮчЕВЫЕ СЛОВА: нелкогольная жировая болезнь печени; инсулинорезистентность; сахарный диабет; Р-селектин.

\section{CHANGES IN P-SELECTIN LEVEL IN BLOOD SERUM IN PATIENTS WITH NON-ALCOHOLIC FATTY LIVER DISEASE}

\author{
@Ye. S. Sirchak, V. I. Griga, A. V. Stegura, A. I. Holcha \\ Uzhhorod National University
}

SUMMARY. Non-alcoholic fatty liver disease (NAFLD) covers a range of diseases closely related to metabolic risk factors. As a result of insulin resistance (IR) in patients with metabolic syndrome, diabetes mellitus (DM) type 2, NAFLD, is forming endothelial dysfunction (DE).

The aim - to investigate the peculiarities of changes in the level of P-selectin in the serum of patients with NAFLD depending on the presence or absence of type 2 diabetes and malnutrition. 
Огляди літератури, оригінальні дослідження, погляд на проблему, випадок з практики, короткі повідомлення

Material and Methods. 104 patients with NAFLD were examined. Patients were distributed as follows: subgroup 1.1 included 22 patients with nonalcoholic fatty hepatosis (NAFH) and IR, subgroup 1.2 consisted of 30 patients with NAFH and type 2 diabetes; subgroup 2.1 included 26 patients with nonalcoholic steatohepatitis (NASH) and IR, and subgroup 2.2 consisted of 26 patients with NAST and type 2 diabetes. All examined patients underwent general clinical studies, as well as determination of serum P-selectin levels.

Results and Discussion. An increase in the level of P-selectin was found in all subgroups of patients examined by us. The stage of increase of its concentration in blood serum with progression of liver damage (from NAFH to NASH), as well as its combination with IR or type 2 diabetes was revealed. Therefore, the maximum level of P-selectin was determined in patients of subgroup $2.2(445.81 \pm 9.13 \mathrm{ng} / \mathrm{ml}, \mathrm{p}<0.01)$, and the minimum in patients of subgroup 1.1 (226.14 \pm $7.56 \mathrm{ng} / \mathrm{ml}, \mathrm{p}<0.05)$.

Conclusions. In patients with NAFLD, an increase in serum P-selectin levels was found, with its maximum deviations from the norm in NASH in combination with type 2 diabetes and minimal changes in patients with NAFH and IR. In patients with NAFLD and carbohydrate metabolism disorders (type 2 diabetes or diabetes mellitus), the level of P-selectin increases in accordance with the increase in body weight index with maximum values in patients with grade II obesity.

KEY WORDS: non-alcoholic fatty liver disease; insulin resistance; diabetes mellitus; P-selectin.

Отримано 17.05.2020 